\title{
MODELING THE EFFICIENCY OF THE STATE AID TO THE DEVELOPMENT OF ELECTRIC VEHICLES
}

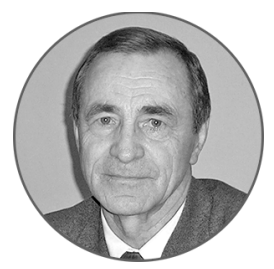

\section{Article history:}

Received 2 November 2017

Received in revised form

4 December 2017

Accepted 11 December 2017

Translated 15 June 2018

Available online 27 June 2018

JEL classification: Q51, 058, R15

Keywords: electric vehicle, econometric modeling, government incentive, deployment policy

\author{
Valerii V. IOSIFOV \\ Kuban State Technological University, Krasnodar, Russian Federation \\ iosifov_v@mail.ru
}

\begin{abstract}
Importance This paper deals with the efficiency of governmental incentives to the market of electric vehicles.

Objectives The paper aims to quantify different governmental incentives through modeling.

Methods The study applies a correlation-regression analysis, test for equality of means for two independent samples, and the Mann-Whitney test.

Results The paper provides models of paired linear regression to describe how governmental subsidies for purchase of electric vehicles (EV) and EV charging infrastructure level influence the EV market volume. Based on the test for equality of means, I found out that preferential parking rates, access to public transport lanes and restricted driving zones, tax credits on EV purchase and preferential electric power supply tariff have no statistically significant impact on the annual EV market volume and EV dissemination. The results were verified through the Mann-Whitney test.

Conclusions and Relevance The received models can be used to forecast parameters of the Russian EV market provided that some governmental incentives are in place.
\end{abstract}

๑) Publishing house FINANCE and CREDIT, 2017

The editor-in-charge of this article was Irina M. Vechkanova Authorized translation by Irina M. Vechkanova

\section{Introduction}

Automotive industry is an important link in the global economic architecture. It contributes about 10 percent to GDP of developed countries (Japan) and creates from one tenth (EU countries) to one sixth (USA) of the total workplaces in the overall industry. Automotive engineering consumes about a half of total oil produced worldwide, over one forth of manufactured glass, generating substantial multiplicative effects [1].

In Russia, the motor vehicle market accounts for 1.5 percent of GDP so far, including dealership and

\footnotetext{
${ }^{\dagger}$ For the source article, please refer to: Иосифов В.В.
} Моделирование эффективности мер государственной поддержки развития электромобильного транспорта. Финансовая аналитика: проблемы и решения. 2018. Т. 11. № 2. С. 140-153.

URL: https://doi.org/10.24891/fa.11.2.140 services, and employs 1.4 million people, with the share of the automotive industry not exceeding 0.5 percent of GDP.

However, demand for automotive products generates the need in high-tech products manufactured in the chemical, metallurgical, electrotechnical and other industries, thus providing jobs to over 3.5 million people $^{1}$ Therefore, the State supports the automotive industry development as one of its priorities.

During the crisis periods of 2008-2009 and 2015-2016, the governmental policy lured automotive

\footnotetext{
${ }^{1}$ Tendentsii razvitiya avtomobil'noi promyshlennosti, resul'taty 2014-2015 godov i srednesrochnye perspektivy razvitiya otrasli [Trends in the automotive industry development. The 2014-2015 results and mid-term prospects of the industry development]. Moscow, Ministry of Economic Development of the Russian Federation, 2016.
} 
manufacturers to localize their production, and directly backed demand. During the 2008-2010 and 2016 periods, the automotive industry received USD 130 billion and USD 113 billion in financial aid for crisis management purposes.

However, despite such considerable allotments from the budget, imported components still have a 72-percent share in automotive production costs, while production output and sales going down annually. Idle production capacities affected financial results of enterprises as their net loss reached RUB 102.3 billion in 2015.

Considering the maturity of global automotive market, the Russian enterprises have little opportunity to increment the production of conventional motor vehicles since similar products of leading manufacturers outperform it technologically and economically. Breakthrough technologies seem to be one of the promising and realistic areas for the State to support the automotive industry since they are intended to address old structural issues of the industry. Such technologies, first of all, include electric vehicle technology, automated driving systems.

Currently, leading car manufacturers actively develop electric and hybrid car programs (Fig. 1) and intellectual car driving systems. If the latter of the technological advancements is in limited use only (mainly in artificial driving scenarios), the first one has already passed the industrial probation.

The global market of electric cars has been rapidly growing for the recent decade, being spurred by various measures of the State aid. Many Russian [2-4] and foreign [5-10] economists delve into the efficiency of such measures. However, governmental incentives have not been quantified yet due to limited statistical data, which the new electric vehicle market has not accumulated sufficiently.

This research aims to construct econometric models to evaluate and forecast quantitative effects of various governmental incentives to electric vehicles.

The pool of information comprises analytical materials of the International Energy Agency $(\text { IEA })^{2}$, national and

\footnotetext{
${ }^{2}$ Global EV Outlook 2016. Beyond One Million Electric Cars. Paris, International Energy Agency, 2016, 51 p.

URL: https://www.iea.org/publications/freepublications/publication/ Global_EV_Outlook_2016.pdf; IEA. Energy Technology Perspectives.
}

regional programs for electric vehicles development in the USA, Japan, France and China $[11]^{3}$.

\section{Analysis of Global Incentives Stimulating Demand for High-Tech Products}

The same principles govern States in supporting the automotive industry likewise the other innovative sectors of economy (for example, renewable energy ${ }^{4}$ ). They can be conditionally divided into measures supporting R\&D, production and demand for innovative technology.

Whereas the automotive industry is a mature sector of economy, in the majority of developed countries R\&D and production development are within the competence of the profit-making segment of national innovative systems [14].

Leading global auto groups make huge financial injections into R\&D every year, being innovative drivers of their national economies (Fig. 2 and 3). For instance, Volkswagen takes the lead among 2,500 global companies benchmarked by their R\&D investment (Industrial R\&D Investment Scoreboard).

Maintaining demand for such auto groups' products, countries follow different strategies by supporting export and conquering foreign markets, fueling the race of standards (for example, environmental footprint) and making public procurement $[2,15]$.

The research referred to herein gives a detailed view of the best-in-class experience in electric vehicles support and development [2]. The scholars highlight financial support measures and various types of non-financial benefits (operational preferences), which car owners may enjoy in various countries.

I analyzed how frequently States resort to various types of governmental incentives to develop the uptake of electric vehicles. As the analysis shows, countries tend

\footnotetext{
Paris, International Energy Agency, 2016.

${ }^{3}$ Paris Declaration on Electro-Mobility and Climate Change and Call to Action. Paris, UNFCCC, 2015. URL:

http://www.iea.org/media/topics/transport/pariselectromobilitydeclarati on.pdf; Compilation of the Road Map for EVs and PHVs toward the Dissemination of Electric Vehicles and Plug-in Hybrid Vehicles. Ministry of Economy, Trade and Industry, 2016.

URL: http://www.meti.go.jp/english/press/2016/0323_01.html

${ }^{4}$ International Tax Incentives for Renewable Energy: Lessons for Public Policy. San Francisco, Center for Resource Solutions, 2005, 27 p. URL: http://dx.doi.org/10.15405/epsbs.2017.01.69
} 
to preferential parking rates, tax benefits for motor vehicle operation (for example, road tax), full or partial sales tax exemption and direct governmental subsidies to reimburse some costs for purchase of an electric vehicle.

As for the amount of subsidies and benefits, they considerably vary and sometimes account for 49 percent of the initial market price of an electric car (Table 1).

Furthermore, electric vehicle charging infrastructure is a crucial and expensive part of the State support to electric vehicle development. The EV charging infrastructure is more often than not formed and developed through the Public Private Partnership mechanism [2].

It is noticeable that demand for electric vehicles is institutionally supported not only in the countries where such vehicles are manufactured (USA, China, Japan, Germany), but also in those ones, which do not yet have EV producing enterprises (Denmark, Norway). Therefore, I did not find an empirical corroboration of the opinion circulating in the literature (for example, in researchers referred herein $[2,16-18]^{5}$ ) stating that national governments support the electric vehicle development with the intention of taking the global technological lead in this area.

\section{Modeling the Impact of Various Governmental Support Measures on the Electric Vehicle Market Indicators}

To construct econometric models reflecting what impact the governmental support measures have on electric vehicles, I rely upon annual reports on the Technology Collaboration Programme on Hybrid and Electric Vehicles of IEA ${ }^{6}$ for 2014-2015 and analytical overview of the global electric vehicle market ${ }^{7}$.

\footnotetext{
${ }^{5}$ Smil V. [All Cars will be electric cars in the near future]. Glavnyi mekhanik = Chief Mechanic, 2011, no. 3, pp. 30-32. (In Russ,); Technology Collaboration Programme on Hybrid and Electric Vehicles (HEV TCP). Hybrid and Electric Vehicles. The Electric Drive Chauffeurs. Annual Report Prepared by the Executive Committee and Task 1 over the Year. Paris, IEA, 2016-2017, 378 p.

${ }^{6}$ HEV TCP Annual Report over 2016: The Electric Drive Chauffeurs. URL: http://www.ieahev.org/news/annual-reports

${ }^{7}$ Global EV Outlook 2016. Beyond One Million Electric Cars. Paris, IEA, 2016, $51 \mathrm{p}$.

URL: https://www.iea.org/publications/freepublications/publication/ Global_EV_Outlook_2016.pdf
}

As the first step, I conducted an investigative correlation analysis in order to trace the closest statistical relationships between quantitative variables, which reflect the situation in the most advanced national markets of electric vehicles, and governmental incentives (Table 2).

Afterwards I forge four models of paired linear regressions for those variables that reveal the closest correlation.

Please find below the model showing the way one-off subsidy for electric vehicle purchase influences the market volume:

$Y=0.017 X$,

where $Y$ stands for the market volume for the year (pcs);

$X$ is an amount of subsidies (EUR).

If viewed through F-test, the model is statistically meaningful for the level $p=0.001$. Standard error of regression coefficient is 0.0025 , coefficient of model determination $R^{2}=85 \%$ (high explanatory level).

Reflecting the impact of the EV charging infrastructure level on the market volume and being built on the U.S. data, Model 1 is expressed as follows:

$Y(t)=38.39 X(t-1)+30,559.82$

where $Y(t)$ is annual market volume within the $t$-period (pcs);

$X(t-1)$ is the number of fast charge devices within the period $t-1$.

If assessed through F-test, the model appears to be statistically meaningful at the level $p=0.01$. By $t$-test, the regression coefficient is of statistical value at the level $p=0.01$, while the model intercept behaves so at the level $p=0.05$. Standard error of the regression coefficient and intercept is 5.22 and $10,798.88$ respectively. The coefficient of $R^{2}$ model coefficient equals 93 percent (high explanatory level).

Reflecting the impact of the EV charging infrastructure level on the market volume and being based on the U.S. data, Model 2 is expressed as follows:

$Y(t)=4.8 X(t-1)+30,564.59$,

where $X(t-1)$ is the number of slow charge devices within the period $t-1$.

Please cite this article as: losifov V.V. Modeling the Efficiency of the State Aid to the Development of Electric Vehicles. Digest Finance, 2018, vol. 23, iss. 2, pp. 133-141. 
If assessed through F-test, the model is of statistical value at the level $p=0.01$. By $t$-test, the regression coefficient is statistically meaningful at the level $p=$ 0.01 , while the intercept of the model behaves so at the level $p=0.05$. Standard error of the regression coefficient and intercept is 0.67 and 10,805.98 respectively. The coefficient of Model 2 determination equals that of Model 1, i.e. 93 percent (high explanatory level of dependent variable).

Reflecting how publicly subsidized cost of electric vehicle influences the uptake of electric vehicles, the model is expressed as follows:

$$
Y=0.265 X
$$

where $Y$ is the uptake of electric vehicles (percentage of all operational electric vehicles);

$X$ is percentage of electric vehicle cost subsidized.

If assessed through F-test, the model appears to be statistically meaningful at the level $p=0.005$. By t-test, the regression coefficient is of statistical value at the level $p=0.005$. standard error of the regression coefficient is 0.073 . The coefficient of determination is 55 percent (medium explanatory level of dependent variable).

To check the impact of other governmental incentives, other than quantitative one (parking benefits, access to public transport lanes, restricted driving zones, preferential electric power supply tariffs and tax credits), I carried out a series of tests for equality of means and Mann-Whitney $U$ tests (the latter is advisable if analyzable samples are not that ample [19]). Table 3 presents results of both tests performed using STATISTICA 10.0 software package.

As the test statistics show, none of the analyzable factors has a statistically meaningful impact on the electric vehicle market indicators (uptake level and market volume). However, it would be erroneous to report that these governmental incentives are ineffective. The governmental incentives are likely to be effective but if they are complemented with more powerful factors, such as subsidizing some part of market value of an electric vehicle and EV charging infrastructure development.

\section{Conclusions}

Reflecting how financial aid influences indicators of national EV markets, the proposed models can be used to forecast the development of the EV market in Russia under certain circumstances (some incentives in place) and decide on those types of incentives which are believed to generate the greatest effect per unit of investment.

Furthermore, the models may help assess how much investment is needed to deploy the EV charging infrastructure and reach certain benchmarks of the national EV market.

It is noteworthy that the proposed models can (and should) be adjusted and get more sophisticated as new statistical data are collected. For example, they might include several regressors instead of one to explain the dependent variable. Presented in the formulas (1)(4), they give just a general outlook of the most common and explicit patterns in the global EV market development. They are not yet configured to some country distinctions, such as the level and dynamics of the vehicle-to-population ratio, cost of conventional fuel (petrol, gas) and electric power tariffs, stringency of local environmental laws, etc. My further research will be dedicated to elaborating the proposed approach by collecting and analyzing new statistical data. 


\section{Table 1}

State subsidy assistance for purchasing and operating an electric vehicle in different countries

\begin{tabular}{llll}
\hline Country & $\begin{array}{l}\text { Percentage of subsidies } \\
\text { of the total price }\end{array}$ & Subsidies (total amount), EUR & One-off subsidy for EV purchase \\
\hline South Korea & 30 & 19,888 & 13,488 \\
\hline Denmark & 49 & 19,466 & 19,466 \\
\hline Norway & 45 & 15,907 & 14,113 \\
\hline China & 23 & 14,469 & 14,469 \\
\hline USA & 18 & 9,319 & 6,989 \\
\hline Spain & 3 & 6,412 & 5,500 \\
\hline France & 18 & 6,300 & 6,300 \\
\hline Netherlands & 17 & 6,188 & 3,380 \\
\hline United Kingdom & 15 & 5,508 & 5,298 \\
\hline Japan & 10 & 4,369 & 4,369 \\
\hline Germany & 13 & 4,360 & 4,000 \\
\hline Sweden & 12 & 4,156 & 4,156 \\
\hline Switzerland & 5 & 1,670 & 1,262 \\
\hline Portugal & 2 & 925 & 331 \\
\hline Italy & 0 & 94 & 94 \\
\hline
\end{tabular}

Source:Authoring based on [22]

Table 2

Results of correlation analysis of the dependence of the EV market indicators on the State support

\begin{tabular}{lllllll}
\hline Indicator & $\begin{array}{l}\text { Share of subsidy } \\
\text { in the value }\end{array}$ & $\begin{array}{l}\text { Total subsidies } \\
\end{array}$ & $\begin{array}{l}\text { One-off } \\
\text { subsidy for EV } \\
\text { purchase }\end{array}$ & Infrastructure level & Uptake of electric vehicles & $\begin{array}{l}\text { Market } \\
\text { volume }\end{array}$ \\
\hline $\begin{array}{l}\text { Share of subsidy } \\
\text { in the value }\end{array}$ & 1 & - & - & - & - & - \\
\hline Total subsidies & 0.75 & 1 & - & - & - & - \\
\hline $\begin{array}{l}\text { One-off subsidy for EV } \\
\text { purchase }\end{array}$ & 0.7 & 0.96 & 1 & - & & - \\
\hline Infrastructure level & 0.77 & 0.89 & 0.84 & 1 & - & - \\
\hline Uptake of electric vehicles & 0.71 & 0.35 & 0.38 & 0.07 & 1 & - \\
\hline Market volume & 0.7 & 0.84 & 0.85 & 0.95 & -0.01 & 1 \\
\hline
\end{tabular}

Source:Authoring

Please cite this article as: losifov V.V. Modeling the Efficiency of the State Aid to the Development of Electric Vehicles. Digest Finance, 2018, vol. 23, iss. 2, pp. 133-141. 
Table 3

Results of the tests for equality of means and Mann-Whitney tests

\begin{tabular}{|c|c|c|c|c|c|}
\hline Dependent variable & $\begin{array}{l}\text { Grouping variable } \\
\text { (factor) (0 - No, } 1 \text { - Yes) }\end{array}$ & $\begin{array}{l}T \text {-test in the test } \\
\text { for equality } \\
\text { of means }\end{array}$ & $\begin{array}{l}p \text {-level } \\
\text { of } t \text {-test }\end{array}$ & $\begin{array}{l}\text { Zof the Mann - } \\
\text { Whitney test }\end{array}$ & $\begin{array}{l}p \text {-level } \\
\text { of } Z \text {-test }\end{array}$ \\
\hline \multirow[t]{4}{*}{ Uptake of electric vehicles } & Parking preferences & -0.16 & 0.87 & 0.94 & 0.34 \\
\hline & $\begin{array}{l}\text { Access to public transport } \\
\text { lanes }\end{array}$ & 1.13 & 0.28 & 1.22 & 0.22 \\
\hline & $\begin{array}{l}\text { Preferential electric } \\
\text { power tariff }\end{array}$ & -0.67 & 0.51 & -0.26 & 0.79 \\
\hline & Tax credit & 0.29 & 0.77 & -1.16 & 0.24 \\
\hline \multirow[t]{4}{*}{ Market volume in 2015} & Parking preferences & 0.34 & 0.75 & 0 & 1 \\
\hline & $\begin{array}{l}\text { Access to public transport } \\
\text { lanes }\end{array}$ & 0.29 & 0.22 & 1.54 & 0.12 \\
\hline & $\begin{array}{l}\text { Preferential electric } \\
\text { power tariff }\end{array}$ & 1.3 & 0.22 & 0.56 & 0.57 \\
\hline & Tax credit & 0.35 & 0.73 & -0.64 & 0.52 \\
\hline
\end{tabular}

Source:Authoring

Figure 1

Trends in the distribution of the leading electric vehicle brands in the U.S. market, 2011-2017, pcs

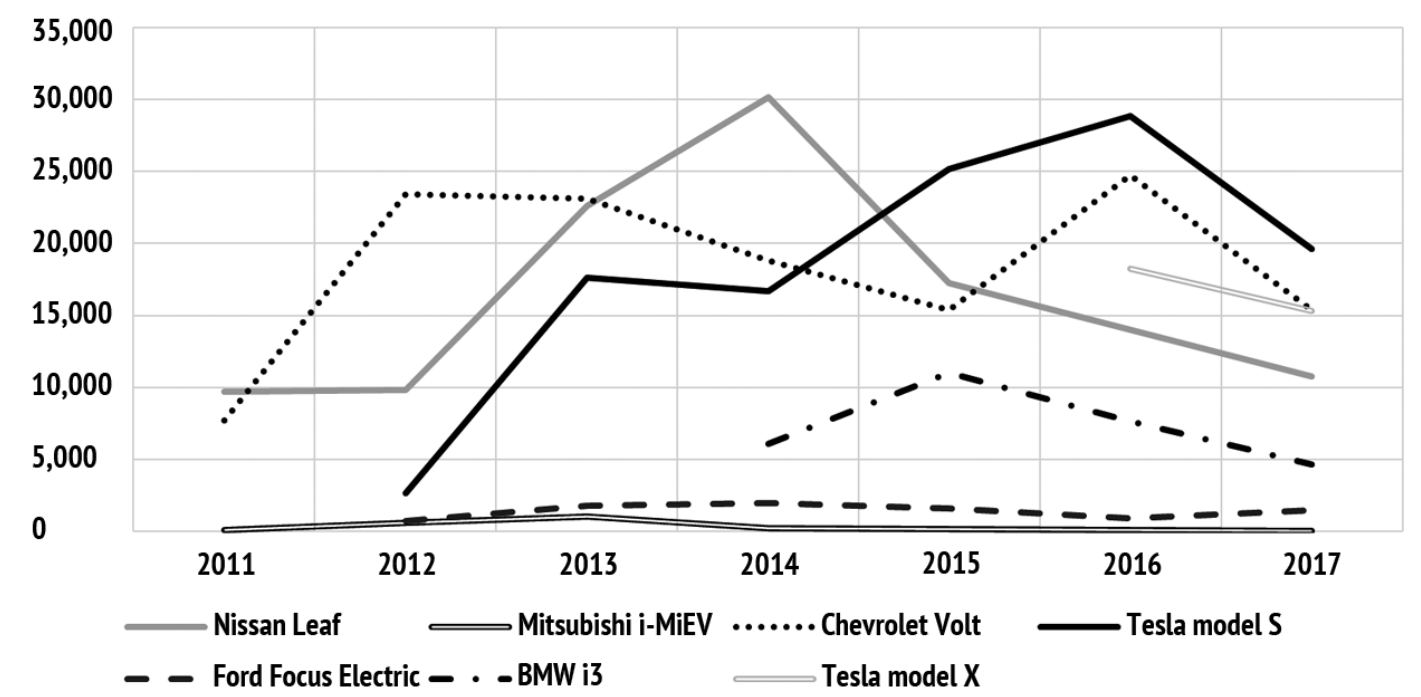

Source : Authoring based on the Inside EVs website data. URL: https://insideevs.com

Please cite this article as: Iosifov V.V. Modeling the Efficiency of the State Aid to the Development of Electric Vehicles. Digest Finance, 2018, vol. 23, iss. 2, pp. 133-141. 


\section{Figure 2}

The share of automotive companies in total funding for R\&D of companies on the Top-50 World Industrial R\&D Scoreboard, 2012-2015

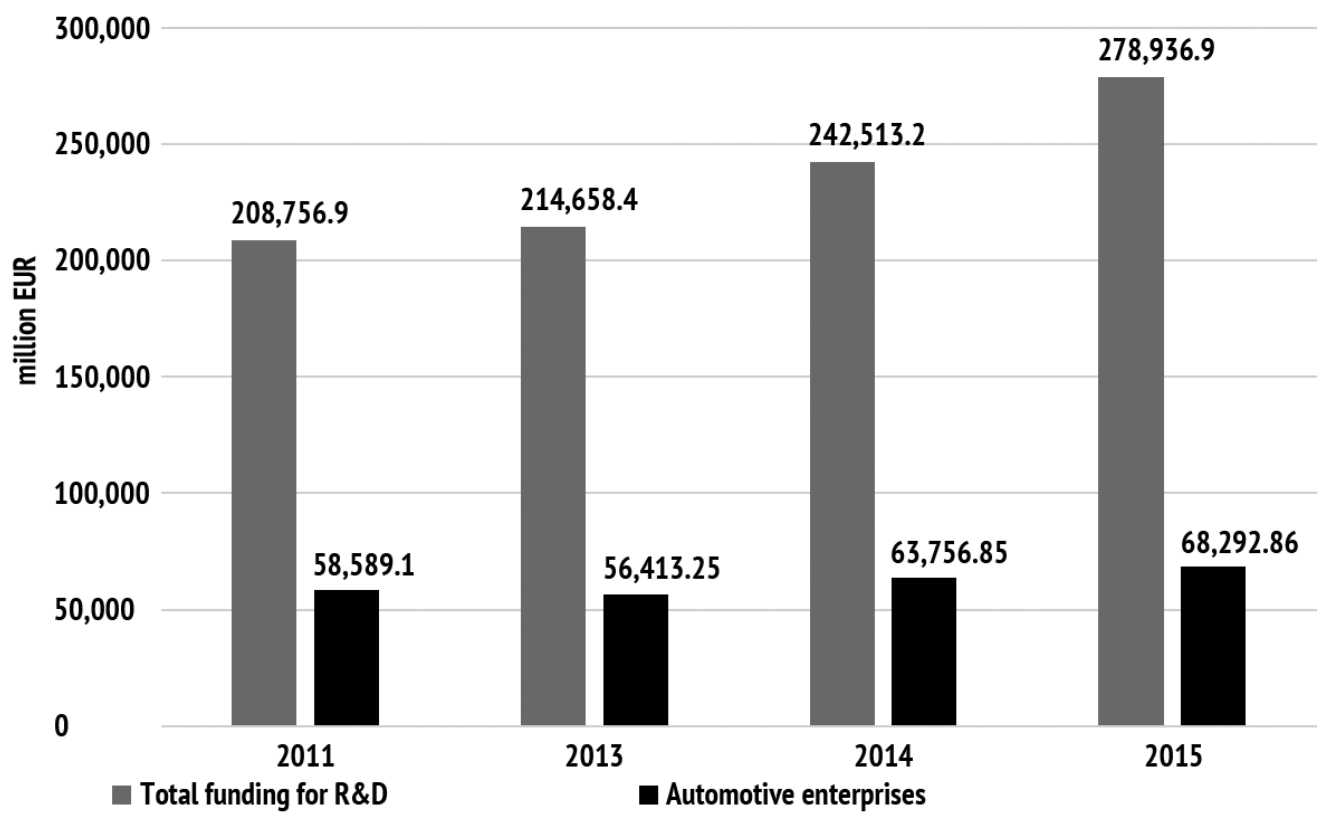

Source:Authoring based on the European Commission Joint Research Center data. URL: http://iri.jrc.ec.europa.eu

\section{Figure 3}

Frequency distribution of various governmental incentives for electric transport development

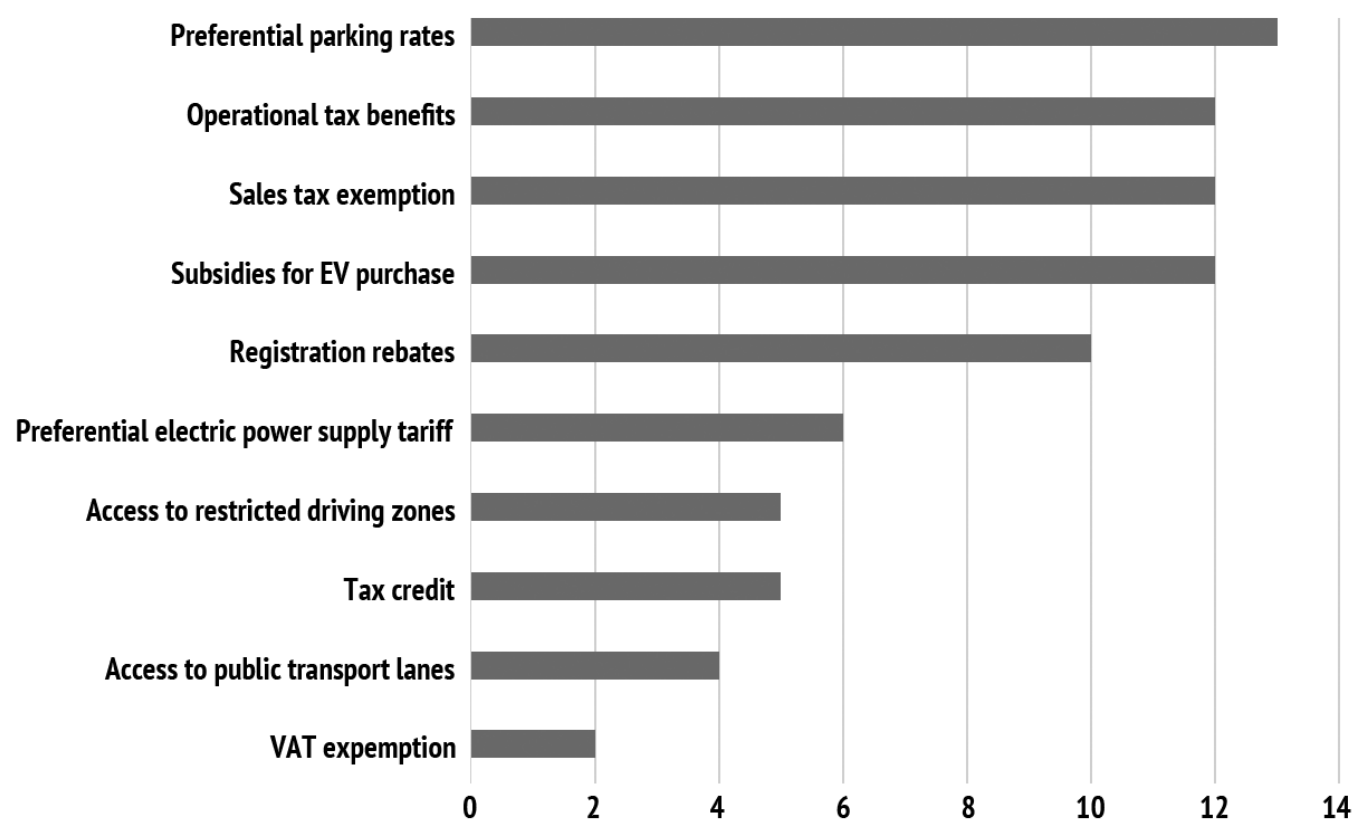

Source:Authoring based on [2]

Please cite this article as: losifov V.V. Modeling the Efficiency of the State Aid to the Development of Electric Vehicles. Digest Finance, 2018, vol. 23, iss. 2, pp. 133-141. 


\section{Acknowledgments}

This research was supported by the Russian Foundation for Basic Research, project No. 17-06-00390, Development of Models for Co-Directed Development of Innovative Motor Transport Technologies and Power Generation Technologies.

\section{References}

1. Shekhtman A.Yu. [The tendencies of development of competition areas in an automobile industry from the world-wide aspect]. Sovremennye problemy nauki i obrazovaniya = Modern Problems of Science and Education, 2015, no. 1, pp. 10-25. URL: https://science-education.ru/ru/article/view?id=17880 (In Russ.)

2. Ratner S.V., Maslova S.S. [State incentives for electric vehicle market development: Best practices]. Finansy $i$ kredit = Finance and Credit, 2017, vol. 23, iss. 22, pp. 1281-1299. (In Russ.) URL: https://doi.org/10.24891/fc.23.22.1281

3. Aleksandrov I.K., Rakov V.A. [A situational analysis on the development of electrical motor transport]. Ekonomicheskii analiz: teoriya i praktika = Economic Analysis: Theory and Practice, 2011, vol. 10, iss. 37, pp. 2-6. URL: https://cyberleninka.ru/article/n/situatsionnyy-analiz-osvoeniya-elektrifitsirovannogo-avtomobilnogotransporta (In Russ.)

4. Ratner S.V., Iosifov V.V. [Modeling the effects of co-directed development of innovations in auto-transportation and electricity generation]. Drukerovskij Vestnik, 2017, no. 3, pp. 49-59. (In Russ.) URL: https://doi.org/10.17213/2312-6469-2017-3-49-59

5. Mersky A.C., Sprei F., Samaras C. et al. Effectiveness of Incentives on Electric Vehicle Adoption in Norway. Transportation Research Part D: Transport and Environment, 2016, no. 46, pp. 56-68. URL: https://doi.org/10.1016/j.trd.2016.03.011

6. Lieven T. Policy Measures to Promote Electric Mobility - A Global Perspective. Transportation Research Part A: Policy and Practice, 2015, no. 82, pp. 78-93. URL: https://doi.org/10.1016/j.tra.2015.09.008

7. Landbroek J.H.M., Franklin J.P., Susilo Y.O. The Effect of Policy Incentives on Electric Vehicle Adoption. Energy Policy, 2016, no. 94, pp. 94-103. URL: https://doi.org/10.1016/j.enpol.2016.03.050

8. Jin L., Searle S., Lutsey N. Evaluation of State-Level U.S. Electric Vehicle Incentives. Washington, DC, USA, International Council on Clean Transportation, 2014, 49 p.

URL: https://www.theicct.org/sites/default/files/publications/ICCT_state-EV-incentives_20141030_0.pdf

9. Nurhadi L., Borén S., Ny H. et al. Competitiveness and Sustainability Effects of Cars and Their Business Models in Swedish Small Town Regions. Journal of Cleaner Production, 2017, vol. 140, iss. 1, pp. 333-348.

URL: https://doi.org/10.1016/j.jclepro.2016.04.045

10. Mock P., Yang Z. Driving Electrification: A Global Comparison of Fiscal Incentive Policy for Electric Vehicles. Washington, DC, USA, International Council on Clean Transportation, 2014, 40 p. URL: https://www.theicct.org/sites/default/files/publications/ICCT_EV-fiscal-incentives_20140506.pdf

11. Li Y. Infrastructure to Facilitate Usage of Electric Vehicles and Its Impact. Transportation Research Procedia, 2016, vol. 14, pp. 2537-2543. URL: https://doi.org/10.1016/j.trpro.2016.05.337

12. Ratner S.V., Aksyuk T.D. [Foreign experience of stimulating microgeneration based on renewable energy sources: organizational and economic aspects]. Nauchno-tekhnicheskie vedomosti SPbGPU. Ekonomicheskie nauki = St. Petersburg Polytechnic University Journal of Engineering Science and Technology. Economic Sciences, 2017, vol. 10, iss. 4, pp. 104-113. (In Russ.) URL: https://doi.org/10.18721/JE.10410

13. Klochkov V.V., Ratner S.V. Upravlenie razvitiem "zelenykh" tekhnologii: ekonomicheskie aspekty [Management of green technologies development: economic issues]. Moscow, Institute of Psychology of RAS Publ., 2013,291 p. URL: http://www.ipu.ru/sites/default/files/page_file/GreenTech.pdf 
14. Golichenko O. The Basic Factors of National Innovation System Development. In: Socio-Economics and Technological Innovations Mechanism and Institutions. Delhi, Narosa Publishing House, 2014, pp. 38-52.

15. Ratner S.V., Iosifov V.V. [Formation of energy engineering markets in China and India]. Vestnik URFU. Seriya: Ekonomika $i$ upravlenie $=$ Bulletin of Ural Federal University. Series: Economics and Management, 2013, no. 3, pp. 52-62. URL: https://vestnik.urfu.ru/fileadmin/user_upload/site_15934/archive/2013/3/06-03-13_Ratner.pdf (In Russ.)

16. Golichenko O.G. [National innovation systems: from conception toward the methodology of analysis]. Voprosy Ekonomiki, 2014, no. 7, pp. 35-50. (In Russ.)

17. Ivlev S.N. [Electric ELLADA - problems of promotion and support measures]. Trudy NAMI, 2014, no. 257, pp. 65-75. (In Russ.)

18. Berndt E.R. Praktika ekonometriki: klassika i sovremennost' [The Practice of Econometrics: Classic and Contemporary]. Moscow, YUNITI-DANA Publ., 2005, 848 p.

19. Aivazyan S.A. Metody ekonometriki [Methods of econometrics]. Moscow, INFRA-M Publ., 2010, 512 p.

\section{Conflict-of-interest notification}

I, the author of this article, bindingly and explicitly declare of the partial and total lack of actual or potential conflict of interest with any other third party whatsoever, which may arise as a result of the publication of this article. This statement relates to the study, data collection and interpretation, writing and preparation of the article, and the decision to submit the manuscript for publication. 